Apidologie, 1983, 14, (1), 29-39.

\title{
HYGIENIC BEHAVIOR OF HONEY BEES IN RELATION TO CHALKBROOD DISEASE
}

\author{
Martha GILLIAM, Stephen TABER III (1) \\ U.S. Department of Agriculture, Agricultural Research Service \\ Carl Hayden Bee Research Center, 2000 East Allen Road, Tucson, Arizona 85719 \\ and \\ Gary V. RICHARDSON \\ U.S. Department of Agriculture, Agricultural Research Service \\ Colorado State University, Economics Building, Fort Collins, Colorado 80521
}

\begin{abstract}
SUMMARY
Colonies of honey bees, Apis mellifera, tested for uncapping and removal of dead brood were classified as resistant or susceptible on the basis of good or poor hygienic behavior, respectively. Colonies determined to be the most resistant or most susceptible were sprayed with suspensions of Ascosphaera apis on the brood and the bees around the brood on alternating days for 2 months. Chalkbrood mummies were collected from dead bee traps placed on the colonies, from landing boards, and from bottom boards. Mummies in uncapped, perforated, and abnormal-appearing comb cells were also counted. At the end of the experiment, brood, bees, and various hive products were examined for growth of A. apis.

Statistical analyses to evaluate the efficiency of removal of the mummies from the colonies classified as resistant or susceptible revealed so much variation from colony to colony and week to week that few significant differences were found between the two groups. However, resistant colonies had higher ratios of efficiency of removal, regardless of how the data were analyzed.

These results indicated that the bees can detect the diseased larvae before we can. Since only $75 \%$ of the mummies were found in dead bee traps, bottom boards as well as dead bee traps must be examined to make accurate counts of mummy removal.

Cultural studies revealed that $A$. apis contaminates more diverse substrates and survives better in bees and hive products from colonies that exhibit poor hygienic behavior. Therefore, good hygienic behavior of bees aids in control of chalkbrood disease by increased removal of dead or diseased brood and also possibly by increased removal or decreased survival of the pathogen.
\end{abstract}

\section{INTRODUCTION}

The incidence and severity of chalkbrood disease of honey bees, Apis mellifera L., caused by the heterothallic fungus, Ascospharea apis Maassen ex Claussen (Olive et Spiltoir), have increased in North America in the past few years (MENAPACE and

(1) Present address : 7052 Pleasants Valley Road, Vacaville, California 95688. 
WiLSON, 1976; NELSON et al., 1976). Larvae with the disease become mummified, and the mummies appear white because of the mycelium of the fungus. However, if mycelia of opposite sexes mate, spores are formed within fruiting bodies, and the mummies become dark gray or black.

No effective chemotherapeutic agent is registered for use against chalkbrood in the United States. Although many researchers have conducted experiments on the use of chemicals to control the disease, most attempts have been unsuccessful because of the toxicity of the chemicals to the bees, the unacceptability of the chemicals to bees, and the time and effort required to disinfect all parts of the hive (for a review see Gilliam, 1978). Because of the difficulties involved in finding an effective chemical control agent and obtaining registration for use in the United States, we decided to initiate studies on genetically controlled nest-cleaning behavior of bees to determine the possibility of developing resistance or control based on the hygienic (housecleaning) behavior of worker bees.

Researchers headed by W. C. RothenbUhLER at Ohio State University found that strains of bees differed in their resistance to American foulbrood disease caused by Bacillus larvae White and that one of the mechanisms of this resistance is related to behavior (for a review see ROTHENBUHLER et al., 1968). Resistant strains quickly removed killed larvae from the comb, and susceptible strains did not (Rothenbuhler, $1964 \mathrm{a}$ ). This hygienic behavior was explained as being controlled by two recessive genes, one for uncapping and one for removal of larvae (ROTHENBUHLER, 1964 b). Housecleaning activity by bees is effective only when both genes are present in homozygosis in a great number of workers.

Our unpublished observations confirmed those of NeLSON et al. (1976) that some bee colonies are more adept at removing chalkbrood mummies than others. Thus, susceptibility and resistance to chalkbrood may be related to housecleaning behavior since uncapping and removal of dead brood would reduce the spread of the pathogen.

In this paper, we report the results of selecting and breeding bees for uncapping behavior and removal of brood killed with dry ice; inoculation with $A$. apis of colonies exhibiting good and poor hygienic behavior; removal of chalkbrood mummies from these colonies by housecleaning bees; and examination of brood, bees, and hive products for $A$. apis. Our results may explain some of the difficulties researchers have experienced in inducing chalkbrood in bee colonies for study (Gilliam et al., 1978).

\section{MATERIALS AND METHODS}

Bee Selection and Breeding

In 1978, 18 nucleus colonies were tested for uncapping and removal of dead brood, and in 1979, 30 full-size colonies were tested. Two tests were made simultaneously on each colony. In the first test 
for removal of dead brood, a 2 -inch-square metal template, whose area delineated 100 cells, was placed on one side of a comb containing unsealed larvae. Dry ice was sprinkled on the larvae within the template area to kill them. Daily observations were made on the number of dead larvae removed by the bees. In the second test, both uncapping and removal behavior of the colonies were tested by cutting from the brood combs of a healthy colony 2 -inch-square sections containing 100 capped brood cells on each side. The comb sections were then placed in a freezer to kill the brood. At the same time that dry ice was sprinkled on the template area in the first test, a 2-inch-square section was cut from the brood comb of each of the colonies and replaced with a comb section containing frozen brood. The bees usually added sufficient wax to secure the test comb section in the comb within 24 hours. Daily observations were made on the number of cells uncapped and empty cells from which brood had been removed. Colonies were then classified as resistant or susceptible on the basis of good or poor uncapping and removal behavior, respectively. The resistant colonies uncapped and removed all the dead brood, and the susceptible ones uncapped and removed dead brood from less than $70 \%$ of the cells.

Queens were reared from each of these colonies by grafting worker larvae. Each was artificially inseminated with $3 \mathrm{ul}$ of semen (usually required 3 drones) from drones from other colonies to minimize progeny variation. These queens were used to head full-size colonies which were tested again for uncapping and removal behavior as described above.

Nine colonies ( 4 resistant and 5 susceptible) were selected for further experimentation with $A$. apis.. These appeared to be the most resistant or most susceptible based on the number of cells that were uncapped and empty.

\section{Ascosphaera apis}

Three black or sporulated mummies were homogenized in $5 \mathrm{ml}$ of $5 \%(\mathrm{w} / \mathrm{v})$ sucrose syrup in a glass tissue grinder. Then $85 \mathrm{ml}$ of sucrose syrup was added to the homogenate, which was then placed in a vial with a screw cap. The inocula were prepared fresh each day before use. They were streaked in duplicate on plates of Sabouraud dextrose agar with $0.2 \%$ yeast extract (SDA-YE) (THOMAS and LUCE, 1972) to check for viability and purity. Wet mounts of the resultant growth were examined microscopically.

Dead bee traps (ATKINs et al., 1970) were placed on each test colony on March 14, 1979. For 3 days, the traps were examined for mummies. Then beginning March 16, the brood and the bees around the brood were sprayed 3 times a day on alternating days (Monday, Wednesday, and Friday) with $30 \mathrm{ml}$ of the homogenate. Spray treatments ended on May 11, 1979.

\section{Collection of Mummies}

From March 19, 1979 to May 17, 1979, mummies were collected daily (Monday through Friday) from the dead bee traps. Twice weekly (Tuesday and Thursday), mummies were collected from the landing boards and bottom boards. White and black mummies from each colony from each collection site were counted and placed in separate vials. Also, twice a week (Tuesday and Thursday) mummies in uncapped cells in the combs were counted. At the same time, cells which were perforated or appeared abnormal in any way were uncapped with forceps to check for mummies, and these data were included in the counts of mummies in combs. Two mummies collected each day from each colony were homogenized and streaked on SDA-YE plates. The resultant growth was examined microscopically in a wet mount preparation to confirm growth of $A$. apis.

\section{Statistical Analyses}

In order to evaluate the efficiency of removal of the mummies for the 4 colonies tclassified as resistant and the 5 colonies classified as susceptible, 5 different percentage efficiencies were calculated from the raw data. These calculations were as follows for each colony:

1. Efficiency Ratio $=\frac{\text { Number of mummies in trap on day } n}{\text { Number of mummies in combs on day } n-1}$

This is a daily estimate for 2 days each week. Mummies in combs were counted only on Tuesday and Thursday. This calculation is subject to large variances because of the use of single point estimators. 


\section{Efficiency Ratio $=\frac{\text { Number of mummies in trap for the week, i.e. Mon. through Fri. }}{\text { (Number of mummies in combs for Tues. and Thurs./2) } \times 7}$}

This is a weekly estimate of efficiency. The trap data in the numerator are the total for 7 days since the Monday trap counts include counts for the weekend. Thus, the average of the two comb counts must be multiplied by 7 to estimate the total mummies in the combs for 7 days.

\section{Efficiency Ratio $=\frac{\text { Number of mummies in trap on Tues. through Fri. \& on following Mon. }}{\text { (Number of mummies in combs Tues., Thurs., \& following Tues. } / 3) \times 7}$}

This is also a weekly estimate of efficiency, but it spatis the weekend and uses three estimates of mummies in combs rather than only two.

4. Efficiency Ratio $=$ Same as $\neq 2$, except that the number of mummies collected from both the landing board and bottom board for the week (Tues. and Thurs.) is added to the numerator.

5. Efficiency Ratio $=$ Same as $\neq 3$, except that the number of mummies collected from both the landing board and bottom board for Tues., Thurs., and the following Tues. is added to the numerator.

These efficiency measures were subjected to analysis of variance for unequal subclass numbers for a mixed model as described by HARVEY (1972). The general linear model was

$$
\mathrm{Y}_{i j k l}=\mu+\mathrm{R}_{i}+\mathrm{C} / \mathrm{R}_{i j}+\mathrm{T}_{k}+\mathrm{RT}_{i k}+e_{i j k l}
$$

where,

$Y_{i j k l}=$ th observation of efficiency at $k$ th time (day or week) from the $j$ th colony with the thesistance class.

$\mu \quad=$ estimate of overall mean.

$\mathbf{R}_{i}=$ effect of resistant or susceptible classification.

$\mathrm{C} / \mathbf{R}_{i j}=$ effect of $j$ th colony within the $\mathbf{R}_{i}$ classification. This is a rendom effect (Error $\mathbf{A}$ ) and tests the resistance effect.

$\mathrm{T}_{k}=$ effect of $k$ th time period (days or weeks)

$\mathbf{R T}_{i j}=$ effect of $i$ th resistance by $j$ th time interaction.

$e_{i j k l}=$ effect of $t h$ observation in the $k$ th time from the $j$ th colony within the th resistance class. This is Error $B$ and tests the time and resistance by time interaction effects.

\section{Plating of Bees and Hive Products for Ascosphaera apis}

At the end of the experiments (May 14-18), the following samples were obtained from each colony possible : 10 adult worker bees ( 5 nurse bees, 5 foragers), 10 apparently healthy worker larvae (5 from unsealed cells, 5 from sealed cells), queen bee, bee bread (stored pollen) from 5 cells (finished with a layer of honey), uncapped brood nest honey from 5 cells, brood food from 5 cells, and 5 adult drones.

Workers, drones, queens, and larvae were individually held with sterile forceps, shaken in tubes containing SDB-YE (same as SDA-YE except contains no agar), and then removed. When growth occurred in the tubes, a loopful of culture was streaked in duplicate onto SDA-YE plates. The guts of the adult bees were aseptically removed, rinsed in 3 washes of sterile distilled water, homogenized in $1.5 \mathrm{ml}$ of sterile distilled water in a tissue grinder, and plated in duplicate on SDA.YE. Each larva was rinsed in sterile distilled water, homogenized in $1.5 \mathrm{ml}$ of sterile distilled water, and plated in duplicate on SDA-YE: Brood food and honey were plated in duplicate directly on SDA-YE. Bee bread from individual cells was homogenized in $1.5 \mathrm{ml}$ of sterile distilled water and plated in duplicate on SDA-YE. All plates were incubated at $26^{\circ} \mathrm{C}$. Wet mounts of resultant growth were prepared and examinited mileroscopically for confirmation of $A$. apis. When no growth occurred after 25 days of incubation, the samples were discarded and considered negative. 


\section{RESULTS AND DISCUSSION}

Table 1 shows the results of the tests for uncapping and removal of dead brood by the 9 colonies that were selected for further testing. These colonies were headed by the artificially inseminated queens, and the tests were performed before treatment with $A$. apis. Based on the results of the tests, colonies were designated as resistant (good housecleaning behavior) or susceptible (poor housecleaning behavior).

All of the resistant colonies removed all the dead unsealed brood within 24 hours. Only one susceptible colony did this. All other susceptible colonies required 48-72 hours to remove all the dead brood.

In the test for uncapping behavior, one resistant colony uncapped all the cells within 24 hours, and the other resistant colonies did so within $\mathbf{4 8}$ hours. None of the susceptible colonies had uncapped all the cells by 96 hours. Only one had uncapped over $90 \%$ of the cells, and another had uncapped only $20 \%$.

Therefore, it appeared that more of the bees possessed the gene for removal than the gene for uncapping. This would indicate that larvae dying in the unsealed cell stage would be removed by all the test colonies, although only the resistant colonies would quickly uncap all cells containing dead brood.

TABL. 1. - Percentages of dead unsealed brood removed and dead sealed brood uncapped by susceptible and resistant colonies ${ }^{a}$.

\begin{tabular}{l|c|c|c|c|c|c|c}
\hline \hline \multirow{2}{*}{} & \multicolumn{2}{|c|}{ Percent brood removed } & \multicolumn{3}{c}{ Percent brood uncapped } \\
\cline { 2 - 8 } Colony & \multicolumn{3}{|c|}{ Hours } & \multicolumn{4}{c}{ Hours } \\
\cline { 2 - 8 } Resistant & 24 & 48 & 72 & 24 & 48 & 72 & 96 \\
HP-2 & & & & & & & \\
CG-2 & 100 & & & 98 & 100 & & \\
CG-3 & 100 & & & 98 & 100 & & \\
CG-12 & 100 & & & 96 & 100 & & \\
Susceptible & 100 & & & 100 & & & \\
HP-4 & & & & & & & \\
CG-6 & 99 & 100 & & 35 & 58 & 67 & 68 \\
CG-13 & 100 & & & 31 & 36 & 84 & 86 \\
CG-19 & 99 & 100 & & 14 & 18 & - & 20 \\
CG-21 & 93 & 100 & & 58 & 82 & 92 & 96 \\
\hline \hline
\end{tabular}

a Percent dead brood removed was determined by killing 100 unsealed larvae with dry ice and determining the number that were removed by the bees. Percent brood uncapped was determined by inserting a comb section with 100 capped cells on each side that had been frozen to kill brood and then counting the number of cells that were uncapped by the bees. 
Raw data subjected to statistical analyses are summarized in Table 2 which shows the numbers of chalkbrood mummies found in comb cells and collected from dead bee traps, landing boards, and bottom boards. Possible misclassification of colonies HP-2 and CG-19 added to the variation between colonies within the treatment groups and affected statistical significance of the data.

Data from each of the 5 calculations of efficiency ratios were subjected to statistical analyses. The results were in general agreement. However, the estimates of experimental variation were quite different. Calculation 1 (daily calculation) had 5-20 times the amount of variation of the weekly estimates. Calculations 2 and 4, which were weekly estimates involving only 2 days of observing mummies in comb cells, were approximately 3 times more variable than calculations 3 and 5, which had 3 estimates of comb cell counts.

TABL. 2. - Total chalkbrood mummies observed or collected.

\begin{tabular}{|c|c|c|c|c|}
\hline \multirow[b]{2}{*}{ Colony } & \multicolumn{4}{|c|}{ Source } \\
\hline & Comb cells & Dead bee trap & Landing board & Bottom board \\
\hline \multicolumn{5}{|l|}{ Resistant } \\
\hline $\begin{array}{c}\text { HP-2 } \\
\text { CG-2 } \\
\text { CG-3 } \\
\text { CG-12 } \\
\text { Average }\end{array}$ & $\begin{array}{r}453 \\
1038 \\
2809 \\
240 \\
1135\end{array}$ & $\begin{array}{l}257 \\
2191 \\
3454 \\
1403 \\
1826\end{array}$ & $\begin{array}{r}0 \\
119 \\
53 \\
24 \\
49\end{array}$ & $\begin{array}{l}835 \\
761 \\
827 \\
179 \\
651\end{array}$ \\
\hline \multicolumn{5}{|l|}{ Susceptible } \\
\hline $\begin{array}{c}\text { HP-4 } \\
\text { CG-6 } \\
\text { CG-13 } \\
\text { CG-19 } \\
\text { CG-21 } \\
\text { Average }\end{array}$ & $\begin{array}{r}388 \\
3210 \\
273 \\
457 \\
452 \\
956\end{array}$ & $\begin{array}{r}229 \\
1375 \\
842 \\
4355 \\
820 \\
1524\end{array}$ & $\begin{array}{r}129 \\
587 \\
65 \\
180 \\
64 \\
205\end{array}$ & $\begin{array}{r}256 \\
524 \\
16 \\
327 \\
87 \\
242\end{array}$ \\
\hline
\end{tabular}

Only the ratios obtained by calculation 5 are presented (Tabl. 3). The ideal ratio would be 1.00 and would indicate that all the mummies seen in the comb cells

TABL. 3. - Efficiency ratios of resistant and susceptible bee colonies across eight weeks as determined by calculation 5 a

\begin{tabular}{|c|c|c|c|c|c|c|c|c|c|}
\hline \multirow[b]{2}{*}{ Treatment group } & \multicolumn{9}{|c|}{ Weeks } \\
\hline & 1 & 2 & 3 & 4 & 5 & 6 & 7 & 8 & Average \\
\hline Resistant & 0.56 & 1.43 & 1.94 & 2.16 & 2.31 & 2.28 & 3.35 & 3.23 & 2.16 \\
\hline Susceptible & 0.91 & 0.74 & 0.92 & 1.47 & 1.72 & 1.76 & 4.44 & 1.98 & 1.74 \\
\hline Average : & 0.74 & 1.09 & 1.43 & 1.82 & 2.01 & 2.02 & 3.90 & 2.61 & \\
\hline
\end{tabular}

a See Statistical Analyses section of Materials and Methods for details. 
were found a day later in the dead bee trap. Thus, we probably underestimated the mummies in the comb cells, or the bees could detect the diseased larvae before we could and removed them. Unfortunately, enough variation from colony to colony existed so that the ratios for the 2 groups were not significantly different. The only significant difference was with the means across time.

The longer the spraying of $A$. apis continued, the faster the bees removed the mummies. Even though the ratio of 4.4 for susceptible colonies at week 7 is questionable, the relative differences between ratios of the two treatment groups favored the resistant colonies by a factor of almost 2 . Resistant colonies had higher efficiency ratios regardless of how the data were analyzed. Thus, we know that there were differences between susceptible and resistant colonies, but we cannot prove this statistically due to the small number of colonies used.

We also recognize that some variation between colonies might have resulted from insemination of queen with semen from more than one drone to obtain the required 3-ul dose. We elected not to attempt single-drone matings of all queens because of potential problems with egg-laying, brood, and queen loss.

We need better detection methods for diseased larvae in comb cells. The ratios obtained show that the bees can detect the abnormal larvae before we can since almost twice the number of mummies that we had observed were removed by the resistant colonies. More frequent counts of mummies in comb cells would have been advantageous to our calculations but disturbing to the bees.

During this study, we collected a total of 19,959 mummies from dead bee traps, bottom boards, and landing boards of the test colonies. Seventy-five percent of the mummies were collected from the dead bee traps, $19 \%$ from bottom boards, and $6 \%$ from landing boards. Those mummies found on landing boards probably would have eventually been found in the dead bee traps. Thus, to make accurate counts of mummies, bottom boards as well as dead bee traps must be examined.

Although sporulated mummies were always used to prepare the spray suspensions, $54.5 \%$ of the total mummies collected from dead bee traps, bottom boards, and landing boards were white or non-sporulated. Since A. apis is heterothallic, a separation of mating types could have occurred, or perhaps, sporulation was in some way inhibited in the larval gut. We also noted in laboratory studies that equal numbers of black and white mummies were produced from inocula prepared from black mummies (GILliam et al., 1978). The possibility also exists that infection in the white mummies could have resulted from hyphae in the sporulated mummies used to prepare inocula. Ninety-five percent of the mummies collected in the present study were workers, and $5 \%$ were drones.

Table 4 shows the results of plating bees and hive products for $A$. apis. The highest number of samples positive for growth of $A$. apis in both resistant and susceptible colonies occurred in bee bread and the guts of nurse bees. Ninety-six 
TABL. 4. - Cultural detection of Ascosphaera apis in bees and hive products of inoculated colonies.

\begin{tabular}{l|r|r}
\hline \multirow{2}{*}{ Sample a } & \multicolumn{2}{|c}{ Number of positive samples } \\
\cline { 2 - 3 } Bee bread & $\mathrm{S}^{\mathbf{b}}$ & $\mathrm{R}$ b \\
Guts of nurse bees & 24 & 13 \\
Guts of foraging bees & 16 & 5 \\
Interior of larvae from capped cells & 3 & 2 \\
Interior of larvae from uncapped cells & 10 & 0 \\
Brood nest honey & 4 & 1 \\
Brood food & 10 & 0 \\
Body surface of uncapped larvae & 2 & 0 \\
Body surface of capped larvae & 1 & 0 \\
Body surface of nurse bees & 0 & 0 \\
Body surface of foraging bees & 0 & 0 \\
Guts of adult drones & 0 & 1 \\
Body surface of drones & 0 & 1 \\
Guts and body surface of queens & 0 & 0 \\
\hline
\end{tabular}

a 25 total samples from $S$ colonies; 20 from $R$ colonies.

${ }^{b} \mathrm{~S}=$ susceptible; $\mathrm{R}=$ resistant

percent of the bee bread samples from susceptible colonies were positive, whereas $65 \%$ from resistant colonies were. Sixty-four percent of the guts of nurse bees sampled from susceptible colonies were positive, and $25 \%$ from resistant colonies were. Nelson and Gochnauer (1982) also found $A$. apis in pollen stored in comb cells of colonies with chalkbrood and in the guts of adult bees from infected colonies. The presence of $A$. apis in guts of nurse bees would result from consumption of contaminated pollen. Higher percentages and more types of samples from susceptible colonies than from resistant colonies contained $A$. apis. For example, A. apis was cultured from the interior of $40 \%$ of capped larvae and $16 \%$ of uncapped larvae sampled from susceptible colonies but $0 \%$ of capped larvae and $5 \%$ of uncapped larvae from resistant colonies. The fungus was also isolated from brood food and honey from susceptible colonies only. Thus, our limited data from colonies that were sprayed with $A$. apis indicate that the fungus contaminates more diverse substrates and survives better in bees and hive products from colonies that exhibit poor hygienic behavior. Additional unpublished data (Gilliam, 1981) revealed $A$. apis in bees and hive products from some colonies for as long as 5 months after the spraying had ceased.

An interesting observation in the present study was the discovery of 8 pupae mummified by $A$. apis. In earlier work, we noted that pupae did not support the growth of $A$. apis in laboratory experiments (Gilliam et al., 1978). Thus, it is possible that the mummified pupae became infected as prepupae but somehow were able to develop into pupae before death occurred. The mummies were smaller than normal pupae but maintained body integrity indicating that they may have been subnormal in some way that allowed them to become mummified. 
Our techniques for testing hygienic behavior of bees may be useful to beekeepers. Replacement of queen bees whose progeny exhibits poor hygienic behavior would be advantageous not only in controlling chalkbrood but other brood diseases as well. A recent popular article described the technique in detail (TABER, 1982).

Received for publication in October 1982.

\title{
ACKNOWLEDGMENTS
}

We thank Brenda J. Lorenz and Gail Durrschmidt for technical assistance.

\author{
ZUSAMMENFASSUNG \\ HYGIENE-VERHALTEN DER HONIGBIENE IN BEZUG AUF DIE KALKBRUT
}

48 Bienenvölker (Apis mellifera) wurden auf die Entdecklung und Entfernung von toter Brut getestet. Auf der Grundlage des guten oder schlechten Hygieneverhaltens wurden die Völker dann als resistent oder anfällig klassifiziert. Von jedem dieser Völker wurden Königinnen nachgezogen und nach künstlicher Besamung zum Aufbau von Völkern benutzt, die wiederum auf das Entdeckeln und Entfernen von toter Brut getestet wurden. Neun Völker, die als resistent bzw, als anfällig klassifiziert waren, wurden für weitere Versuche mit Ascosphaera apis ausgewählt, dem Pilz, der die Kalkbrutkrankheit der Bienenbrut verursacht.

Suspensionen von Ascosphaera apis, hergestellt aus sporulierten Kalkbrutmumien, wurden 3 mal täglich an alternierenden Tagen zwei Monate lang auf die Brut und auf die Bienen in deren Nähe gesprüht. Mumien wurden aus an den Kästen angebrachten Fallen für tote Bienen, von den Anflugbrettern und von den Bodenbrettern gesammelt. Die Mumien in ungedeckelten, perforierten oder in abnormen Wabenzellen wurden ebenfalls gezählt.

Am Ende des Versuchs wurden Brut, Bienen und verschiedene Stockprodukte auf das Vorhandensein von $A$. apis untersucht.

Die statistischen Analysen zur Bewertung der Effizienz der Entdeckelung der Mumien von den als resistent oder anfällig klassifizierten Völkern ergaben eine derart große Variation von Volk zu Volk und von Woche zu Woche, daß zwischen diesen beiden Gruppen nur wenige signifikante Unterschiede gefunden wurden. Es hatten jedoch resistente Völker einen höheren Wirkungsgrad der Larvenentfernung, unabhängig davon auf welche Weise die Daten analysiert wurden.

Diese Ergebnisse weisen darauf hin, daß die Bienen die erkrankten Larven früher erkennen können als wir. Da nur $75 \%$ der Mumien in den Fallen gefunden wurden, müssen zur genauen Auszählung der aus den Zellen entfernten Mumien neben den Fallen für tote Bienen auch die Bodenbretter untersucht werden.

Ascosphaera apis konnte aus $96 \%$ der Proben von Pollenvorräten aus anfälligen und aus $65 \%$ der Proben aus resistenten Völkern kultiviert werden. Ebenso enthielt in $64 \%$ der Fälle der Darm von Bienen aus anfälligen Völkern $A$. apis, aber nur in $25 \%$ von solchen aus resistenten Völkern. Sowohl die. Zahl der Probentypen (dh. Larven, Honig und Brutnahrung) wie der Befallsgrad von A. apis innerhalb jeder Probentype war für die anfälligen Völker größer als für die resistenten. Es scheint also der Pilz in Völkern mit schlechtem Hygieneverhalten mehr verschiedenartige Substanzen zu kontaminieren und in den Bienen und Stockprodukten besser zu gedeihen. 


\section{RÉSUMÉ \\ COMPORTEMENT D'HYGIÈNE DES ABEILLES LIÉ AU COUVAIN PLÂTRÉ}

On a testé les capacités de 48 colonies d'abeilles, Apis mellifica, à désoperculer et vider les cellules renfermant du couvain mort, ce qui a permis de les classer ensuite en colonies résistantes ou colonies sensibles selon qu'elles avaient fait preuve d'un bon ou d'un faible comportement d'hygiène. Des reines ont été élevées dans chacune de ces colonies, inséminées artificiellement puis introduites dans des colonies qui ont été testées à nouveau. On a sélectionné 9 colonies considérées comme étant les plus résistantes ou les plus sensibles pour d'autres expériences avec Ascosphaera apis, le champignon responsable de la maladie du couvain plâtré. Des suspensions d'A. apis ont été préparées à partir de momies de couvain plâtré et répandues sur le couvain et sur les abeilles présentes autour, 3 fois par jour, tous les deux jours pendant deux mois. On a récolté les momies dans des trappes à abeilles mortes fixées à la planche de vol et au plancher de la ruche. On a aussi dénombré les momies dans les cellules non operculées, perforées ou d'aspect anormal. A la fin de l'expérience on a examiné la capacité de développement d'A. apis sur le couvain, les abeilles et les divers produits du rucher.

Les analyses statistiques effectuées pour évaluer l'efficacité de l'évacuation des momies des colonies classées comme résistantes ou sensibles ont montré tant de variations d'une colonie à l'autre et d'une semaine à l'autre que l'on a trouvé peu de différences significatives entre les deux groupes. On a trouvé néanmoins chez des colonies résistantes des quotients plus élevés d'efficacité de l'évacuation, sans tenir compte de la façon dont les données ont été analysées.

Ces résultats prouvent que les abeilles peuvent détecter avant nous les larves malades. Puisque l'on n'a trouvé que $75 \%$ des momies dans les trappes à abeilles mortes, il est nécessaire d'examiner aussi les planchers des ruches pour chiffrer avec précision l'évacuation des momies.

On a pu faire la culture d'A. apis à partir de $96 \%$ des échantillons de pain d'abeilles (pollen stocké dans les cellules des rayons) provenant des colonies sensibles et à partir de $65 \%$ des échantillons provenant de colonies résistantes. Les intestins des nourrices prélevées dans les colonies sensibles renfermaient $A$. apis à $64 \%$, ceux des nourrices des colonies résistantes à $25 \%$ seulement. Le nombre de types d'échantillons (i.e. larves, miel et nourriture larvaire) et l'incidence d' $A$. apis au sein de chaque type d'échantillon étaient tous deux plus élevés chez les colonies sensibles que chez les colonies résistantes. Le champignon semble donc contaminer des substrats plus variés et mieux survivre dans les abeilles et les produits de la ruche de colonies qui présentent un comportement d'hygiène peu développé.

\section{REFERENCES}

AtKins E. L., Todd F. E., Anderson L. D., 1970. - Honey bee field research aided by Todd dead bee hive entrance trap. Calif. Agr., 24, 12-13.

Gilliam M., 1978. - Fungi. In "Honey Bee Pests, Predators, and Diseases ", ed. R. A. Morse, 78-101, Cornell University Press, Ithaca.

Gilliam M., Taber III S., Rose J. B., 1978. - Chalkbrood disease of honey bees, Apis mellifera L. : a progress report. Apidologie, 9, 75-89.

HARVEY W. R., 1972. - General outline of computing procedures for six types of mixed models. Animal Sciences Department, Ohio State University, Columbus.

MENAPACE D. M., WiLSON W. T., 1976. - The spread of chalkbrood in the North American honey bee. Amer. Bee J., 116, 570-573. 
Nelson D. L., Gochnauer T. A., 1982. - Field and laboratory studies on chalkbrood disease of honey bees. Amer. Bee J., 122, 29-32.

Nelson D. L., Barker R., Bland E., Corner J., Soehngen U., Villeneuve J.L., 1976. - Chalk brood disease survey of honey bees in Canada, 1975. Amer. Bee J., 116, 108-109.

ROTHENBuhleR W. C., 1964 a. - Behaviour genetics of nest cleaning in honey bees. I. Responses of four inbred lines to disease-killed brood. Anim. Behav., 12, 578-583.

ROTHENBUHLER W. C., $1964 \mathrm{~b}$. - Behaviour genetics of nest cleaning in honey bees. IV. Responses of $F_{t}$ and backcross generations to disease-killed brood. Amer. Zoologist, 4, 111-123.

Rothenbuhler W. C., KulinceviC J. M., KerR W. E., 1968. - Bee genetics. Ann. Rev. Genetics, 2, 413-438.

TABer S., 1982. - Bee behavior. Determining resistance to brood diseases. Amer. Bee J, 122, 422-425.

Thomas G. M., LuCE A., 1972. - An epizootic of chalk brood, Ascosphaera apis (Maaseen ex Claussen) Olive and Spiltoir in the honey bee, Apis mellifera L. in California. Amer. Bee J., 112, 88-90. 